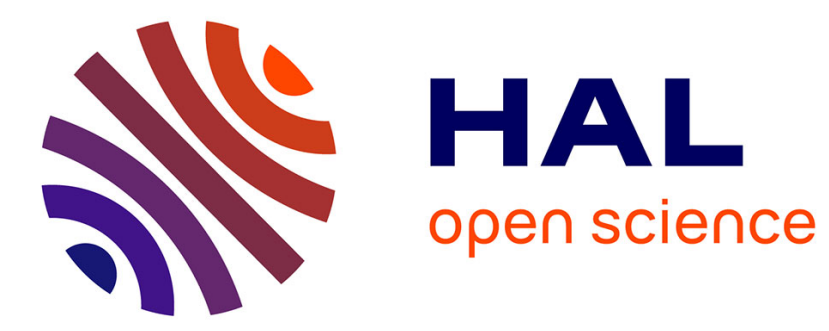

\title{
Effect of sediment grain-size on development of brown ring disease in the Manila clam Ruditapes philippinarum
}

Jonathan Flye-Sainte-Marie, Fred Jean, Susan Ford, Christine Paillard

\section{To cite this version:}

Jonathan Flye-Sainte-Marie, Fred Jean, Susan Ford, Christine Paillard. Effect of sediment grain-size on development of brown ring disease in the Manila clam Ruditapes philippinarum. Aquaculture, 2008, 278 (1-4), pp.184-187. 10.1016/j.aquaculture.2008.03.013 . hal-00452260

\section{HAL Id: hal-00452260 \\ https://hal.univ-brest.fr/hal-00452260}

Submitted on 2 Feb 2010

HAL is a multi-disciplinary open access archive for the deposit and dissemination of scientific research documents, whether they are published or not. The documents may come from teaching and research institutions in France or abroad, or from public or private research centers.
L'archive ouverte pluridisciplinaire HAL, est destinée au dépôt et à la diffusion de documents scientifiques de niveau recherche, publiés ou non, émanant des établissements d'enseignement et de recherche français ou étrangers, des laboratoires publics ou privés. 


\title{
Effect of sediment grain-size on development of brown ring disease in the Manila clam Ruditapes philippinarum
}

\author{
Jonathan Flye-Sainte-Marie ${ }^{\mathrm{a}, \mathrm{b}, *}$, Fred Jean ${ }^{\mathrm{a}, \mathrm{b}}$, Susan E. Ford ${ }^{\mathrm{c}}$, \\ Christine Paillard ${ }^{\mathrm{a}, \mathrm{b}}$ \\ ${ }^{a}$ Université de Bretagne Occidentale, IUEM, Brest, France \\ ${ }^{\mathrm{b}}$ CNRS (CNRS/INSU) LEMAR UMR 6539, Place N. Copernic, 29280 Plouzané, France \\ ${ }^{\mathrm{c}}$ Haskin Shellfish Research Laboratory, Rutgers University, 6959 Miller Avenue, Port Norris, \\ NJ 08349, USA
}

\begin{abstract}
Brown ring disase (BRD) in the Manila clam is induced by the bacterium Vibrio tapetis. During the infection process, the pathogen enters the extrapallial compartment of the Manila clam and induces the formation of a characteristic brown deposit that gives the disease its name. Although post-infection processes have been widely described for this disease, the mechanisms of entry of the bacteria into the extrapallial compartment remains unclear. From relationships between clam size and BRD prevalence, and between grain-size distribution in natural habitats and prevalence, we propose a simple explanation for this step: $V$. tapetis benefits from mechanical disruptions of the periostracal lamina or valve margins to colonize the extrapallial compartment. Such disruptions may be induced by the presence of large sediment grains in natural habitats, which become lodged in the shell opening. This hypothesis suggests that limiting handling of clams may help to limit development of BRD in cultured clam beds.
\end{abstract}

Key words: Manila clam, brown ring disease, BRD, Vibrio tapetis, prevalence, clam size, sediment grain-size

\section{Introduction}

The Manila clam, Ruditapes philippinarum, was introduced in France for aquaculture purposes between 1972 and 1975 (Flassch and Leborgne, 1992). In France, this venerid

* Coresponding author. E-mail address: jonathan.flye@univ-brest.fr (J. Flye-Sainte-Marie) 
culture became increasingly widespread, and since 1988 natural populations have colonized most embayments along the French Atlantic coast, resulting in important fisheries.

Brown ring disease (BRD) in this species is a bacterial disease induced by the pathogen Vibrio tapetis. It was first observed in 1987 in northern Brittany (France) and has rapidly been reported along the French Atlantic coast (Paillard, 1992). The disease is now observed along the entire European Atlantic coast, from Norway to southern Spain, and in Italy (Paillard, 2004b; Paillard, unpublished data). The disease, which causes mass mortalities in cultured clam beds, has severely affected venerid culture in northern Brittany but has a lower impact in natural beds, where maximum prevalence reaches only $30 \%$ (Paillard, 2004b).

During the infection process, the pathogen proliferates within the extrapallial compartment and disrupts the normal production of periostracal lamina, inducing the formation of a brown conchiolin deposit on the inner shell; this characteristic clinical sign gave the disease its name (Paillard, 1992). BRD progression has been described in depth in Paillard et al. (1994) and Paillard (2004b). The following steps for the disease progression have been proposed by Paillard (2004b) : (1) adherence of the pathogen, $V$. tapetis, to the periostracal lamina; (2) penetration and colonization of the extrapallial compartment; and (3) formation of the anomalous brown conchiolin deposit, in which the pathogen becomes embedded. Althougth post-infection processes (i.e. after penetration into extrapallial compartment) have been widely described (see Paillard, 2004b, for a review), mechanisms of entry of $V$. tapetis into the extrapallial fluids remain poorly understood. Paillard (2004b) stated that "in favourable conditions for the pathogen, $V$. tapetis colonization provokes some alteration and rupture of the periostracal lamina which allows the penetration of the bacteria into the extrapallial fluids". By revisiting three unpublished data sets, we propose a simple hypothesis to explain the entry of $V$. tapetis into the extrapallial compartment.

\section{Methods}

All three data sets were collected from intertidal natural populations in the Gulf of Morbihan (southern Brittany, France) between 1999 and 2006 (Fig. 1). For all data sets, BRD signs in the clams were monitored on the inner surface of the clam shells according to the criteria of Paillard and Maes (1994) in which conchiolin deposits stages (CDS) range from microscopic brown spots on the inner face of the shell in the earliest stage (CDS 1), to a thick brown deposit covering most of the inner shell in the most advanced stage (CDS 7).

The first data set came from a monthly monitoring of haemocyte parameters of Manila clams at Ile de Bailleron (Fig. 1, site A) (Flye-Sainte-Marie et al., unpublished data). During this survey, a total of 17 samples of 60 clams each was collected between the $6^{\text {th }}$ of July 2004 and the $20^{\text {th }}$ of September 2005 (total : 1020 individuals). This survey included individuals from a wide size range: from $26 \mathrm{~mm}$ to $55 \mathrm{~mm}$ (mean $=37.80 \mathrm{~mm}, \mathrm{SD}=4.46)$ along the maximum length axis. The prevalence of $\mathrm{BRD}$ was low (mean $=9.7 \%, \mathrm{SD}=3.5 \%$ ) 


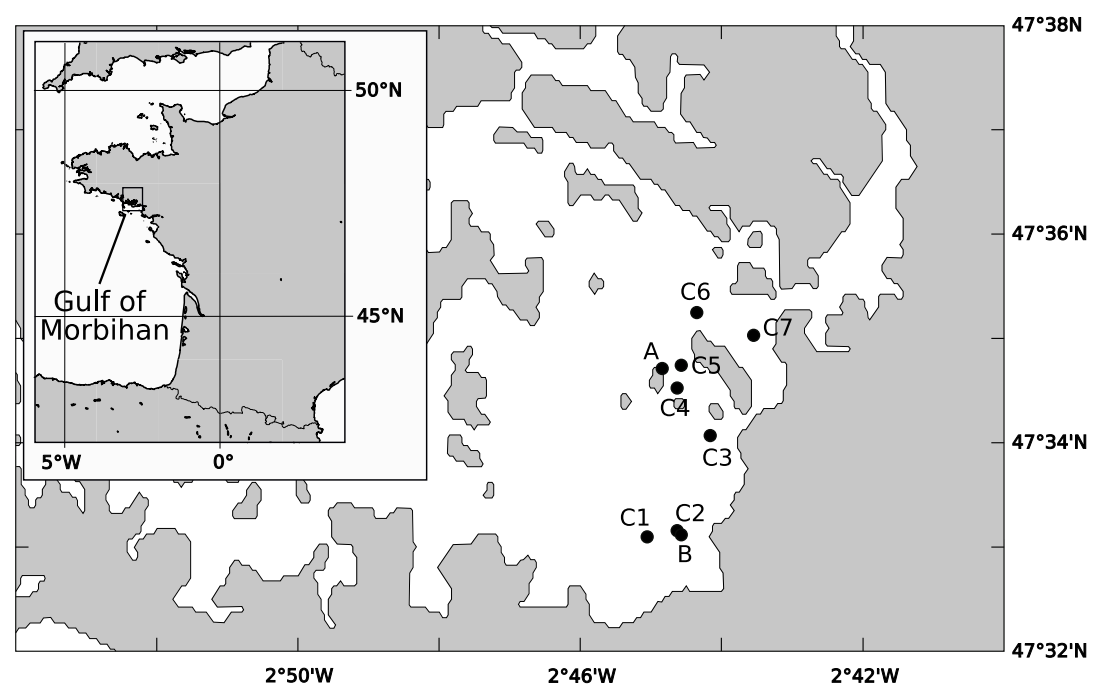

Fig. 1. Map of the sampling sites of the data sets used for this study. A: Ile de Bailleron; B: Ile aux Oiseaux. C1-C7: Sampling sites of the third data set.

and showed no significant variation during the sampling period $\left(\chi^{2}=12.96, d f=16\right.$, $p=0.675$ ), allowing pooling of the whole data set in order to extract a size-prevalence relationship. In this data set, disease intensity was also low: $80 \%$ of the affected clams had a CDS of 3 or less.

The second data set was collected on the $29^{\text {th }}$ of March 2006 in Ile aux Oiseaux (Fig. 1, site B). A total of 530 individuals was collected and the size ranged from $11 \mathrm{~mm}$ to $42 \mathrm{~mm}$ (mean $=28.01 \mathrm{~mm}, \mathrm{SD}=6.49)$. In this data set, disease prevalence and intensity were also low: average prevalence was $4.1 \%$ and $80 \%$ of the affected clams presented a CDS of 3 or less.

For these two data sets, individuals were distributed into 2-mm size classes; prevalence (percentage of affected individuals) was calculated for each size class. Size classes with fewer than 40 individuals (left and right tails of the size distributions) were excluded from computations. Relationships between clam size and prevalence were analysed using linear models, the $p$-value corresponds to the significance of the linear model (i.e. probability of the difference between the value of the slope and 0 ).

The third data set came from a survey of Manila clam density, BRD prevalence and Vibrio tapetis abundance in the sediment, as estimated by an ELISA test (Allam et al., 2002) in the Gulf of Morbihan during 1999 (Paillard, unpublished data). During this study, sediment cores were collected at some of the sampling stations. Grain-size distribution in sediment cores was measured following Weiss and Frock (1976). For seven stations (Fig. 1, sites $\mathrm{C} 1-\mathrm{C} 7$ ) both BRD prevalence and grain-size distribution were available, which allowed analysis of the relationship between those two parameters. For this purpose, the relationship between the grain size of the upper $5 \%$ fractile of the sediment and prevalence was analysed using a linear model. In these samples, average clam size ranged from $32.92 \mathrm{~mm}(\mathrm{SD}=4.24)$ to $34.49 \mathrm{~mm}(\mathrm{SD}=5.98)$ and there were no significant differences 

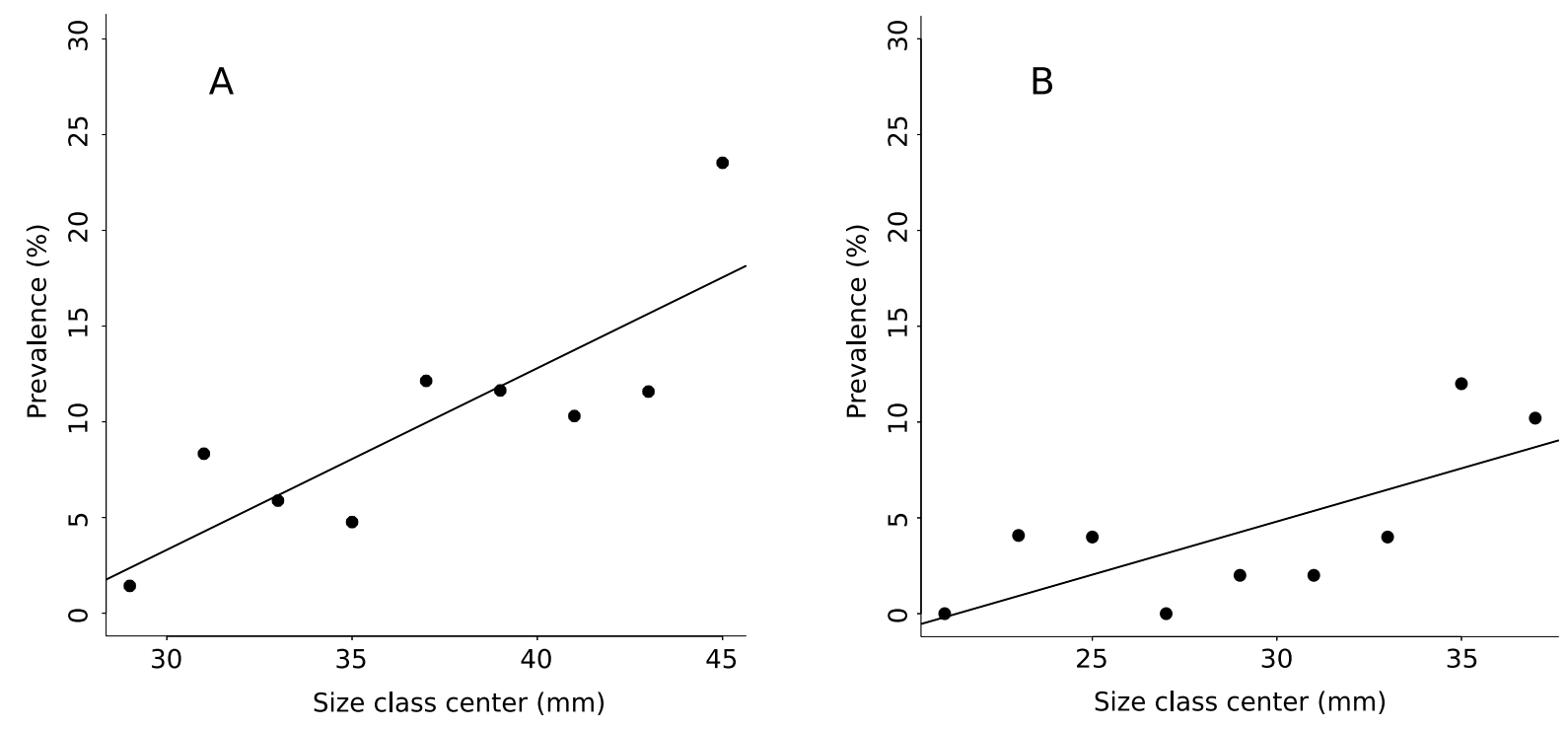

Fig. 2. Relationship between center of the size classes and prevalence in the data set from (A) Ile de Bailleron $\left(y=0.94 x-0.25 ; r^{2}=0.52 ; p=0.005\right)$ and the data set from (B) Ile aux Oiseaux $\left(y=0.55 x-0.12 ; r^{2}=0.66 ; p=0.028\right)$

in clam length between samples (Kruskall Wallis, $\chi^{2}=9.03, d f=6, p=0.171$ ).

\section{Results and discussion}

Figure 2 illustrates the relationships between clam size and BRD prevalence for the data sets from Ile de Bailleron (Fig. 2 A) and from Ile aux Oiseaux (Fig. 2 B). For both data sets, correlation coefficients were high $\left(r^{2}>0.50\right)$ and slopes were significant $(p<0.05)$, clearly indicating a positive relationship between clam size and BRD prevalence in natural populations. Such a pattern has been widely described for parasitic disease of filter feeding bivalves and is attributed to the greater probability that a larger (and presumably older) individual (1) has been exposed to potential infections longer and (2) has a higher filtration capacity and resulting higher probability of encountering parasites, compared to a small clam (see e.g. Andrews and Hewatt, 1957; Guralnick et al., 2004; Villalba et al., 2005).

Figure 3 shows the relationship between the grain size of the upper $5 \%$ fractile of the sediment in localized habitats (Fig. 1, sites $\mathrm{C} 1-\mathrm{C} 7$ ) and the BRD prevalence. For this relationship, the correlation coefficient was high $\left(r^{2}=0.74\right)$ and slope was significant $(p$ $=0.013$ ), indicating a significant positive correlation of prevalence with the abundance of large particles in the sediment. This relationship suggests an increased probability of infection linked to the abundance of large particles in the sediment.

From these relationships, it can be hypothesized that a factor contributing to the initiation of the infection (i.e. the entry of $V$. tapetis into the Manila clam extrapallial compartment) is a mechanical rupture of the periostracal lamina or chipping of the valve margins induced by mechanical impact with large sediment particles. In the sediment, when a clam is active, 


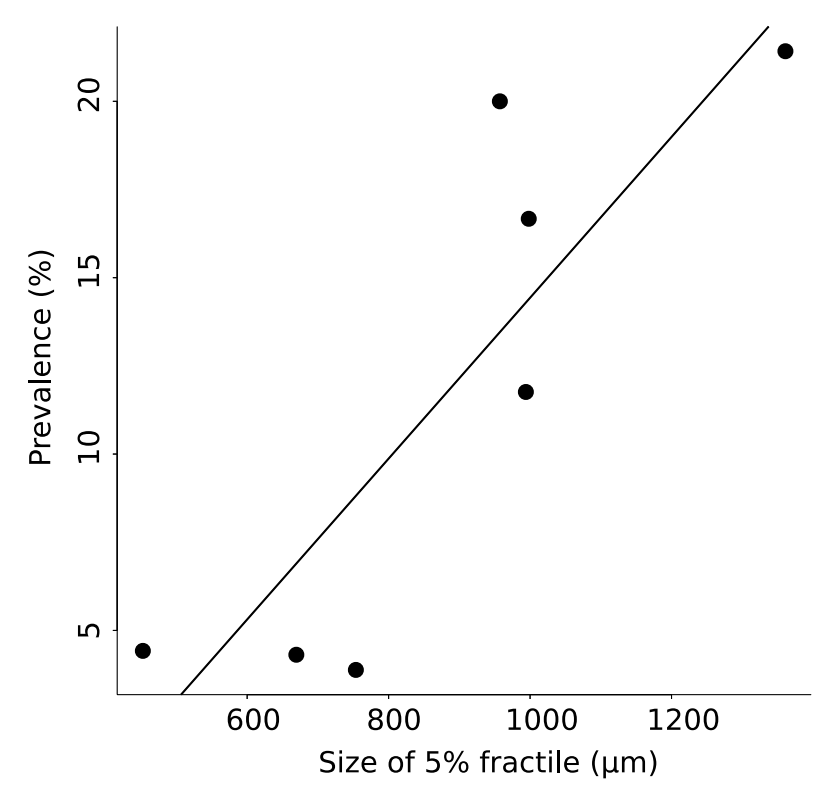

Fig. 3. Relationship between grain size of the upper $5 \%$ fractile of the sediment and BRD prevalence in the sampling stations of the third data set from Gulf of Morbihan (see Fig. 1, sites C1-C7 $) ;\left(y=0.0228 x-8.37 ; r^{2}=0.74 ; p=0.013\right)$.

its siphons are extended out of the shell and in direct contact with the sediment; when the siphons retract, sediment particles adherent in siphon mucus, may be trapped between the valve margins. Moreover, sediment particles may be trapped within the shell aperture. When the clam closes its valves, these particles may disrupt the periostracal lamina or chip the shell edge, thereby opening a portal of entry for the pathogen $V$. tapetis. Since siphon surface area and shell aperture length are directly related to clam size, the probability of trapping a potentially deleterious sediment particle may increase with size, providing an additional potential explanation for the size/BRD relationship in natural populations. This hypothesis may also explain why early clinical signs are frequently observed in the siphonal area (Goulletquer et al., 1989; Paillard, 1992; Paillard et al., 1994; Paillard and Maes, 1994).

Seasonal variations in BRD are not always observed, especially when average prevalence is low (first data set; Paillard, 2004a). Epidemiological surveys of BRD showed that affected clams are found throughout the year, but generally, the prevalence of BRD signs increases toward the beginning of the spring and decreases toward the beginning of the summer (Paillard et al., 1997; Paillard, 2004a). Low temperatures during the rising phase of prevalence have been suggested to explain this pattern (Paillard et al., 1997, 2004; Paillard, 2004a,b). However, this period also coincides with the beginning of the growth season (Goulletquer, 1989); the newly calcified layer on the valve margins may be more susceptible to mechanical disruption. Therefore, disruptions of the periostracal lamina and valve margins may occur more frequently during this period. Thus, seasonality of BRD development could be explained both by low temperatures and weakness of the valve margins. 


\section{Conclusion}

This study suggest that the pathogen $V$. tapetis may benefit from mechanical disruption of the periostracal lamina or the valve margins to colonize the Manila clam extrapallial compartment. These disruptions may be induced by the presence of large sediment grains. This simple hypothesis provides a valuable explanation for some of the observed BRD development patterns. In cultured clam beds, limiting rough handling of clams, especially at the beginning of the growth season (spring), may help to limit development of BRD.

\section{Acknowledgments}

This work was funded by the Région Bretagne within the MODELMAB research program, and was part of a CNRS/NSF joint program on marine disease modeling. The authors thank Lionel Alanno for technical assistance during field work. This is contribution $\mathrm{N}^{\circ} \mathrm{XXXX}$ of the IUEM (Brest, France).

\section{References}

Allam, B., Paillard, C., Ford, S. E., 2002. Pathogenicity of Vibrio tapetis, the etiological agent of Brown Ring Disease (BRD) in clams. Dis. Aquat. Org. 48, 221-231.

Andrews, J. D., Hewatt, W. G., 1957. Oyster mortality studies in Virginia. II. the fungus disease caused by Dermocystidium marinum in oysters of Chesapeake Bay. Ecol. Monogr. 27 (1), 1.264.

Flassch, J. P., Leborgne, Y., 1992. Introduction in Europe, from 1972 to 1980, of the Japanese Manila clam (Tapes philippinarum) and effects on aquaculture production and natural settlement. ICES Marine Symposium 194, 92-96.

Goulletquer, P., 1989. Etude des facteurs environnementaux intervenant sur la production de le palourde japonaise d'élevage Ruditapes philippinarum. Thèse de Doctorat, Université de Bretagne Occidentale, Brest.

Goulletquer, P., Héral, M., Bechemin, C., Richard, P., 1989. Abnormal calcification in the shell of the manila clams Ruditapes philippinarum: characterization and comparison of amino-acid content in different shell parts. Aquaculture 81, 169-183.

Guralnick, R., Hall, E., Perkins, S., 2004. A comparative approach to understanding causes and consequences of mollusc-digenean size relationships: A case study with allocreadiid trematodes and Cyclocalyx clams. J. Parasitol. 90 (6), 1253-1262.

Paillard, C., 1992. Etiologie et caractérisation de la maladie de l'anneau brun chez la palourde d'élevage, Ruditapes philippinarum. Thèse de Doctorat, Université de Bretagne Occidentale, Brest.

Paillard, C., 2004a. Rôle de l'environnement dans les interactions hôtes-pathogènes; 
développement d'un modèle de vibriose chez les bivalves. Habilitation à diriger des recherches (HDR), Université de Bretagne Occidentale, Brest.

Paillard, C., 2004b. A short-review of brown ring disease, a vibriosis affecting clams, Ruditapes philippinarum and Ruditapes decussatus. Aquat. Living Resour. 17, 467-475. Paillard, C., Allam, B., Oubella, R., 2004. Effect of temperature on defense parameters in Manila clams Ruditapes philippinarum challenged with Vibrio tapetis. Dis. Aquat. Org. 59, 249-262.

Paillard, C., Maes, P., 1994. Brown ring disease in the Manila clam Ruditapes philippinarum: establishment of a classification system. Dis. Aquat. Org. 19, 137-146.

Paillard, C., Maes, P., Mazurie, J., Claude, S., Marhic, A., Le Pennec, M., 1997. Epidemiological survey of the brown ring disease in clams of Atlantic coast : role of temperature in variation of prevalence. Proceedings of the VIIIe Symposium of the International Society for Veterinary Epidemiology and Economics, 31/32, 14.03.1-14.03.3.

Paillard, C., Maes, P., Oubella, R., 1994. Brown ring disease in clams. Ann. Rev. Fish Dis. 4, 219-240.

Villalba, A., Casas, S., Lopez, C., Carballal, M., 2005. Study of perkinsosis in the carpet shell clam Tapes decussatus in Galicia (NW Spain). II. Temporal pattern of disease dynamics and association with clam mortality. Dis. Aquat. Org. 65 (3), 257-267.

Weiss, E. L., Frock, H. N., 1976. Rapid analysis of particle size distributions by laser light scattering. Powder Technology 14 (2), 287-93. 